\title{
Relation of cardiac complications to SGOT level in acute myocardial infarction
}

\author{
B. L. Chapman ${ }^{1}$ \\ From the Department of Medicine, The Royal Newcastle Hospital, \\ Newcastle, New South Wales, 2300, Australia
}

The incidence of each of the commoner cardiac complications of acute myocardial infarction was correlated with the serum aspartic aminotransferase (SGOT) level in cases treated in a coronary care unit. There was a highly significant linear correlation between SGOT level and the incidence of supraventricular and ventricular arrhythmias, complete heart block, bundle-branch block, myocardial insufficiency, and secondary cardiac arrest. Increasing SGOT levels were accompanied by an increasing incidence of each of these complications except sinus bradycardia, whose incidence decreased. The distribution of primary cardiac arrest was independent of the SGOT level.

These results were interpreted as showing that the cardiac complications occur with a frequency which is in direct proportion to the size of the infarct. Other workers have shown that the height to which the SGOT rises is proportional to the volume of infarcted myocardium.

It was further suggested that, in cases treated in a coronary care unit, these complications are only indirectly related to the mortality rate, their presence merely reflecting the extent of infarction. Each of the complications whose incidence increased with the SGOT level was shown in a previous paper to be associated with an increase in the mortality rate, whereas sinus bradycardia was associated with a decrease. Primary cardiac arrest was associated with no change. The overall mortality rate was previously shown to have a highly significant linear correlation with the SGOT level. It was emphasized, however, that the present study does not exclude the possibility that some cardiac complications may exert an influence on the mortality rate over and above that which is indirect and merely a reflection of the extent of infarction present.

In the course of an examination of the interrelation between the various prognostic factors in acute myocardial infarction, the incidence of cardiac complications was correlated with the serum enzyme levels. The results of some of these correlations are now presented. The enzyme studied was the SGOT, and the complications examined were the more common arrhythmias and conduction defects, myocardial insufficiency, and cardiac arrest.

\section{Subjects and methods}

This is part of a prospective study of patients treated in the coronary care unit of the Royal Newcastle Hospital. The criteria for the diagnosis of acute myocardial infarction and its complications, the methods and duration of observation, and the treatments used have been described (Chapman, 1970, 1971a). The SGOT was estim-

Received 28 October 197 I.

1 Present address: West Middlesex Hospital, Isleworth, Middlesex. ated at 24 hours from infarction, but for reasons mentioned previously (Chapman, 197Ib) a result was not available in all cases.

The data were originally punched into paper tape for the earlier analyses on an NCR 500 computer. It was subsequently transferred to magnetic tape and then to punched cards for some complex analyses using a CDC 3200 computer. The sorting for the present study was done concurrently with these. The statistical methods used have been referred to (Chapman, I97Ib). The calculations were performed on a CASIO AL-1000 programmable electronic calculating machine. Since for SGOT levels above 200 Sigma-Frankel units $/ \mathrm{ml}$ the actual values were not reported, an upper limit of 500 units $/ \mathrm{ml}$ was assumed. On the graphs, intervals representing twice the standard error of estimate above and below the regression lines are shown with broken lines. The coordinates of the points and the ends of the lines are given in Tables $\mathbf{I}$ and 2.

Acute myocardial infarction was confirmed in 495 of the 774 cases admitted to the unit in the 21 months from August 1968. An acceptable 24-hour SGOT estimate was available in 357 of these. The 
TABLE I Co-ordinates of points on graphs

\begin{tabular}{|c|c|c|c|c|c|c|c|c|c|c|}
\hline \multirow{2}{*}{$\begin{array}{l}\text { Fig. } \\
\text { No. }\end{array}$} & \multirow[t]{2}{*}{ Variable correlated with SGOT } & \multicolumn{9}{|l|}{ Co-ordinates } \\
\hline & & Horizontal & $50 \cdot 5$ & $70 \cdot 5$ & $90 \cdot 5$ & 110.5 & $130 \cdot 5$ & 150.5 & $180 \cdot 5$ & $350 \cdot 5$ \\
\hline $\mathbf{I}$ & Sinus tachycardia & & $37 \cdot 5$ & $40 \cdot 6$ & $46 \cdot 3$ & $84 \cdot 0$ & $48 \cdot 4$ & $66 \cdot 7$ & $33 \cdot 7$ & $66 \cdot 7$ \\
\hline 2 & Sinus bradycardia & & II $\cdot \mathbf{I}$ & $29 \cdot 0$ & $14 \cdot 6$ & $20 \cdot 0$ & $38 \cdot 7$ & $19 \cdot 0$ & $19 \cdot 0$ & $6 \cdot 4$ \\
\hline 3 & Supraventricular ectopic beats & & $33 \cdot 3$ & $33 \cdot 3$ & $42 \cdot 5$ & $44 \cdot 0$ & $50 \cdot 0$ & $47 \cdot 6$ & $28 \cdot 6$ & $50 \cdot 0$ \\
\hline 4 & Supraventricular tachycardia & & 6.9 & $3 \cdot \mathbf{I}$ & I7·I & $16 \cdot 0$ & $9 \cdot 7$ & $19 \cdot 0$ & $4 \cdot 8$ & $25 \cdot 0$ \\
\hline 5 & Atrial fibrillation & & II $\cdot \mathbf{I}$ & $9 \cdot 4$ & $4 \cdot 9$ & $16 \cdot 0$ & $6 \cdot 5$ & $14 \cdot 3$ & I9.I & $22 \cdot 9$ \\
\hline 6 & Ventricular ectopic beats & & $63 \cdot 9$ & $62 \cdot 5$ & $70 \cdot 7$ & $56 \cdot 0$ & $80 \cdot 6$ & $7 I \cdot 4$ & $81 \cdot 0$ & $79 \cdot 1$ \\
\hline 7 & Ventricular tachycardia & & 4.2 & $3 \cdot 1$ & $9 \cdot 8$ & $8 \cdot 0$ & $12 \cdot 9$ & $19 \cdot 0$ & $14: 3$ & $29 \cdot 2$ \\
\hline 8 & Ventricular asystole & Vertical & $7 \cdot 0$ & 0.0 & $7 \cdot 3$ & $0 \cdot 0$ & $6 \cdot 5$ & $4 \cdot 8$ & $14 \cdot 3$ & $33 \cdot 3$ \\
\hline 9 & Ventricular fibrillation & & $6 \cdot 9$ & $3 \cdot 1$ & $7 \cdot 3$ & $8 \cdot 0$ & $3 \cdot 2$ & $9 \cdot 5$ & $4 \cdot 8$ & $29 \cdot 2$ \\
\hline IO & Complete heart block & & $4 \cdot 2$ & $6 \cdot 2$ & $7 \cdot 3$ & $8 \cdot 0$ & 19.4 & $14 \cdot 3$ & $19 \cdot 0$ & $25 \cdot 0$ \\
\hline I I & Complete bundle-branch block & & $8 \cdot 4$ & $9 \cdot 4$ & $17 \cdot 1$ & $8 \cdot 0$ & $6 \cdot 4$ & $14 \cdot 3$ & $14 \cdot 3$ & $23 \cdot 4$ \\
\hline 12 & Cardiac failure & & $65 \cdot 3$ & $62 \cdot 5$ & $78 \cdot 0$ & $92 \cdot 0$ & $77 \cdot 4$ & $85 \cdot 7$ & $7 x \cdot 4$ & $91 \cdot 7$ \\
\hline I3 & Pulmonary oedema & & $12 \cdot 5$ & $9 \cdot 4$ & $7 \cdot 3$ & $24 \cdot 0$ & $3 \cdot 2$ & $0 \cdot 0$ & 0.0 & $22 \cdot 9$ \\
\hline I4 & Cardiogenic shock & & $15 \cdot 3$ & I5.6 & 14.6 & $24 \cdot 0$ & $22 \cdot 6$ & 9.5 & $28 \cdot 6$ & $54 \cdot 2$ \\
\hline I5 & Primary cardiac arrest & & $2 \cdot 8$ & $3 \cdot \mathbf{I}$ & 0.0 & 0.0 & $3 \cdot 2$ & $4 \cdot 8$ & 0.0 & $2 \cdot 1$ \\
\hline I6 & Secondary cardiac arrest & & II $\cdot \mathbf{I}$ & $6 \cdot 2$ & $22 \cdot 0$ & $12 \cdot 0$ & $12 \cdot 9$ & $4 \cdot 8$ & $14 \cdot 3$ & $60 \cdot 4$ \\
\hline
\end{tabular}

present study was confined to the 29I cases in whom the SGOT level exceeded 40 SigmaFrankel units/ml.

\section{Results}

With increasing SGOT levels there was an increasing incidence of the supraventricular arrhythmias other than sinus bradycardia, the ventricular arrhythmias, complete heart block, bundle-branch block, all degrees of myocardial insufficiency, and secondary cardiac arrest. Thus, there was an increasing incidence, as the SGOT level rose, of sinus tachycardia (Fig. I), supraventricular ectopic beats (Fig. 3), supraventricular tachycardia (Fig. 4), and atrial fibrillation (Fig. 5). The pattern was similar for ventricular ectopic beats (Fig. 6), ventricular tachycardia (Fig. 7), asystole (Fig. 8), and ventricular fibrillation (Fig. 9). The incidence of complete heart block (Fig. 10) and of bundle-branch block (Fig. I I) also increased with the SGOT level. This occurred similarly with cardiac failure (Fig. 12), pulmonary oedema (Fig. 13), and cardiogenic shock (Fig. 14). The same trend applied for secondary cardiac arrest (Fig. I6).

The incidence of sinus bradycardia, by contrast, fell as the SGOT level rose (Fig. 2).

TABLE 2 Co-ordinates of ends of lines on graphs

\begin{tabular}{|c|c|c|c|c|c|c|c|c|}
\hline \multirow{4}{*}{$\begin{array}{l}\text { Fig. } \\
\text { No. }\end{array}$} & \multirow[t]{4}{*}{ Variable correlated with SGOT } & \multicolumn{7}{|l|}{ Co-ordinates } \\
\hline & & & \multicolumn{2}{|c|}{ Regression line } & \multicolumn{2}{|c|}{$\begin{array}{l}\text { Upper broken } \\
\text { line }\end{array}$} & \multicolumn{2}{|c|}{$\begin{array}{l}\text { Lower broken } \\
\text { line }\end{array}$} \\
\hline & & & From & To & From & To & From & To \\
\hline & & Horizontal & $50 \cdot 5$ & $350 \cdot 5$ & $50 \cdot 5$ & $350 \cdot 5$ & $50 \cdot 5$ & $350 \cdot 5$ \\
\hline I & Sinus tachycardia & & $43 \cdot 8$ & $68 \cdot 0$ & $69 \cdot 8$ & $94 \cdot 0$ & $17 \cdot 8$ & $42 \cdot 0$ \\
\hline 2 & Sinus bradycardia & & $20 \cdot 4$ & 10.9 & $38 \cdot 8$ & $29 \cdot 3$ & $2 \cdot 0$ & $-7 \cdot 5$ \\
\hline 3 & Supraventricular ectopic beats & & $36 \cdot 7$ & $50 \cdot 6$ & $48 \cdot 7$ & $62 \cdot 6$ & $24 \cdot 7$ & $38 \cdot 6$ \\
\hline 4 & Supraventricular tachycardia & & $7 \cdot 9$ & 29.4 & 17.7 & $39 \cdot 2$ & $-I \cdot 9$ & $19 \cdot 6$ \\
\hline 5 & Atrial fibrillation & & $8 \cdot 6$ & $22 \cdot 7$ & $15 \cdot 8$ & $29 \cdot 9$ & $\mathrm{I} \cdot 4$ & 15.5 \\
\hline 6 & Ventricular ectopic beats & & $65 \cdot 3$ & $81 \cdot 6$ & 74.5 & $90 \cdot 8$ & $56 \cdot \mathrm{I}$ & $72 \cdot 4$ \\
\hline $\begin{array}{l}7 \\
8\end{array}$ & $\begin{array}{l}\text { Ventricular tachycardia } \\
\text { Ventricular asystole }\end{array}$ & Vertical & $\begin{array}{l}4 \cdot 7 \\
1 \cdot 8\end{array}$ & $\begin{array}{l}29 \cdot 9 \\
31 \cdot 0\end{array}$ & $\begin{array}{r}9 \cdot 1 \\
10 \cdot 4\end{array}$ & $\begin{array}{l}34 \cdot 3 \\
39 \cdot 6\end{array}$ & $\begin{array}{r}0.3 \\
-6.8\end{array}$ & $\begin{array}{l}25 \cdot 5 \\
22 \cdot 4\end{array}$ \\
\hline 9 & Ventricular fibrillation & & $3 \cdot 2$ & $26 \cdot 4$ & $10 \cdot 8$ & 34.0 & $-4 \cdot 4$ & 18.8 \\
\hline 10 & Complete heart block & & $5 \cdot 9$ & $26 \cdot 9$ & II 9 & $32 \cdot 9$ & -0.1 & 20.9 \\
\hline II & Complete bundle-branch block & & $8 \cdot 7$ & $22 \cdot 8$ & $15 \cdot 3$ & $29 \cdot 4$ & $2 \cdot I$ & $16 \cdot 2$ \\
\hline 12 & Cardiac failure & & $69 \cdot 7$ & $93 \cdot 5$ & 84.5 & $108 \cdot 3$ & $54 \cdot 9$ & $78 \cdot 7$ \\
\hline 13 & Pulmonary oedema & & $8 \cdot 4$ & $18 \cdot 6$ & $22 \cdot 8$ & $33 \cdot 0$ & $-6 \cdot 0$ & $4 \cdot 2$ \\
\hline 14 & Cardiogenic shock & & $12 \cdot \mathbf{I}$ & $51 \cdot 9$ & $21 \cdot 9$ & $6 I \cdot 7$ & $2 \cdot 3$ & $42 \cdot 1$ \\
\hline I5 & Primary cardiac arrest & & $2 \cdot I$ & $1 \cdot 9$ & $5 \cdot 1$ & $4 \cdot 9$ & -0.9 & $-I \cdot I$ \\
\hline 16 & Secondary cardiac arrest & & $6 \cdot 0$ & 54.9 & $22 \cdot 0$ & $70 \cdot 9$ & $-10 \cdot 0$ & $38 \cdot 9$ \\
\hline
\end{tabular}



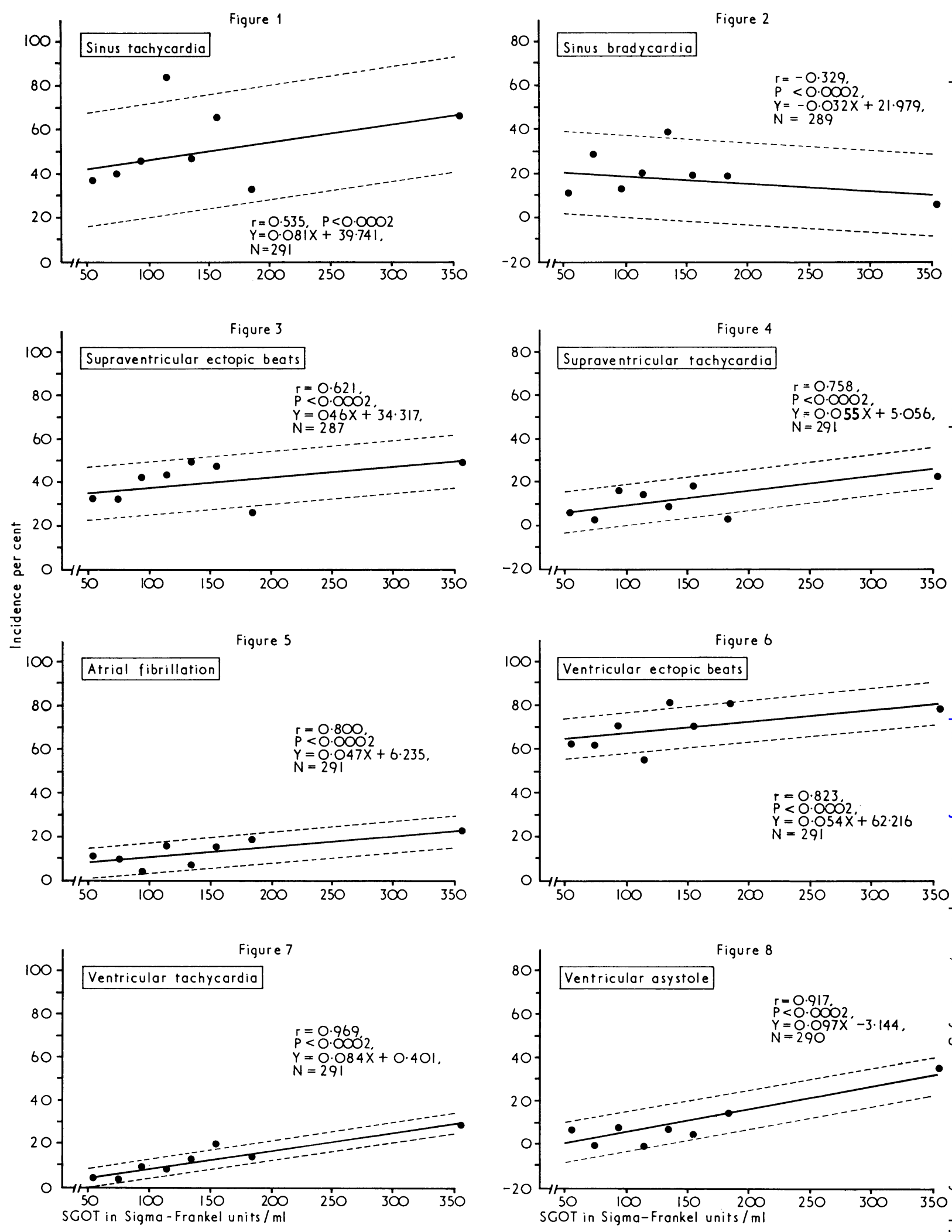

FIG. I-8 Correlation and regression of incidence of various factors on SGOT level. 

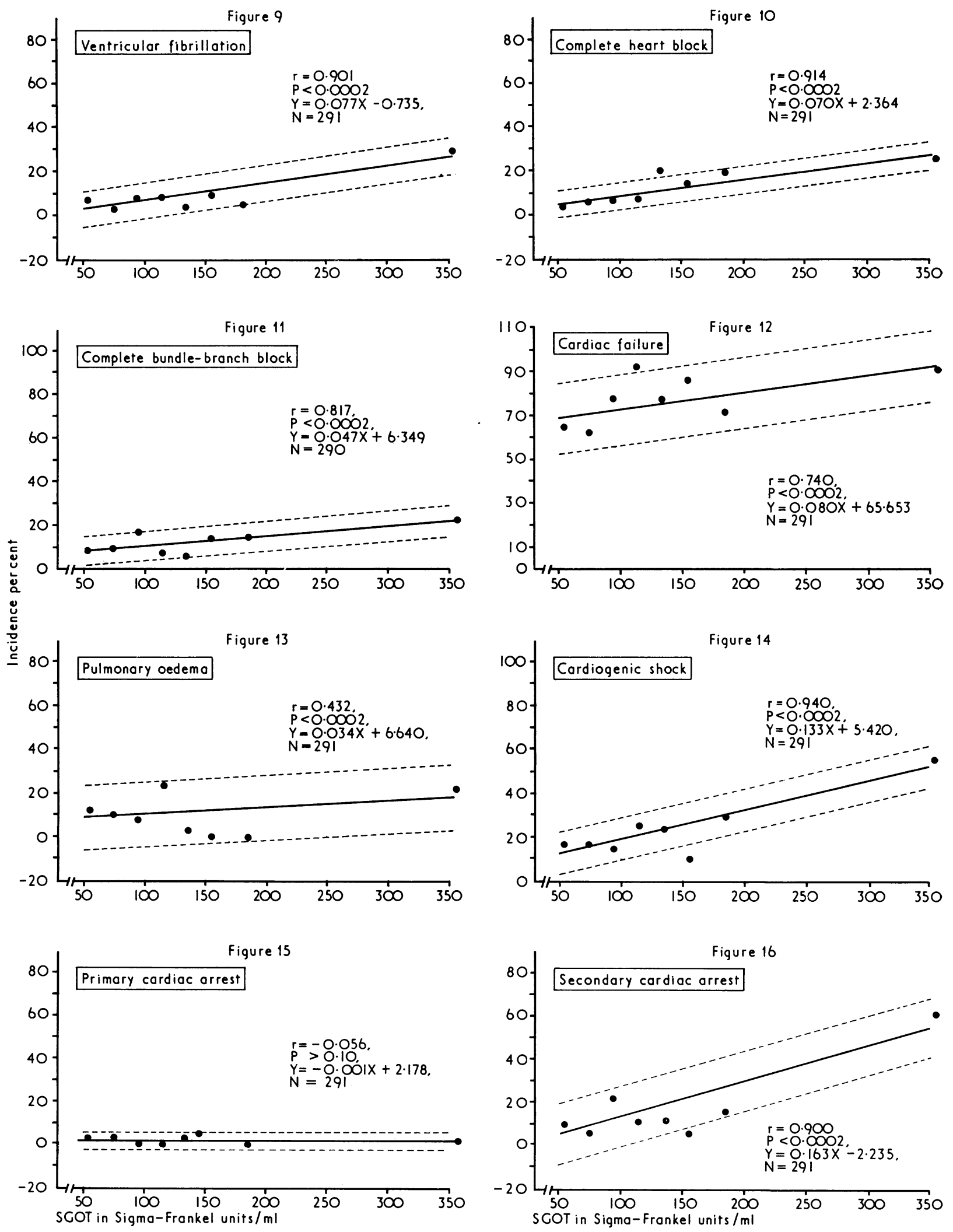

FIG. 9-I6 Correlation and regression of incidence of various factors on SGOT level. 
Primary cardiac arrest was different again, in that its distribution was independent of the SGOT level (Fig. I5).

For every complication except primary cardiac arrest, the relation between incidence and SGOT level was linear (Fig. I-I4, I6). Among those complications whose incidence increased with the SGOT level (Fig. I, 3-I4, I6), the correlation coefficients ranged from 0.969 for ventricular tachycardia (Fig. 7) down to 0.432 for pulmonary oedema (Fig. 13). For sinus bradycardia with its diminishing incidence, the coefficient was -0.329 (Fig. 2). Each of these correlation coefficients differed from zero to a statistically highly significant degree $(P<0.0002)$. Only for primary cardiac arrest was the coefficient insignificant $(P>0 \cdot 10)$.

The calculated regression lines for incidence on SGOT level sloped upwards for the majority of complications (Fig. I, 3-14, I6), but downwards for sinus bradycardia (Fig. 2). For primary cardiac arrest, the line was practically horizontal (Fig. I5).

\section{Discussion}

The results are interpreted as showing that the cardiac complications of acute myocardial infarction occur with a frequency which is in direct proportion to the size of the infarct. There was a highly significant linear correlation between SGOT level and the incidence of supraventricular and ventricular arrhythmias, complete heart block, bundle-branch block, myocardial insufficiency, and secondary cardiac arrest. As the SGOT increased, so did the incidence of all of these complications except sinus bradycardia, whose incidence decreased. It has been shown that the height to which the SGOT rises is proportional to the volume of infarcted myocardium (West, Eshchar, and Zimmerman, 1966; Killen and Tinsley, I966; Kibe and Nilsson, 1967; Whitby, 1968).

It is further suggested that, in cases treated in a coronary care unit, the cardiac complications are only indirectly related to the mortality rate, their presence merely reflecting the extent of infarction. Each of those complications whose incidence increased in a linear fashion with the SGOT level was previously shown to be associated with an increase in the mortality rate, even if not always statistically significant (Chapman, r971a). Similarly, sinus bradycardia, whose incidence diminished as the SGOT rose, was found to be associated with a decrease in the mortality rate. The occurrence of primary cardiac arrest, which was independent of the enzyme level, had no effect on the mortality rate. It was also shown previously that there was a highly significant linear relation between the overall mortality rate and the SGOT level, practically all of the variation in the former being explained by variation in the height of the latter (Chapman, I97Ib).

It is emphasized, however, that the present study was restricted to the correlation of the incidence of these complications with the SGOT level. It does not exclude the possibility that some cardiac complications may exert an influence on the mortality rate over and above that which is indirect and merely a reflection of the extent of infarction present. There is evidence, for instance, that cardiogenic shock may be responsible for an extension of the original infarct, presumably because of diminished coronary perfusion (Page et al., 1971). This may not necessarily be reflected in the peak enzyme levels. Furthermore, similar changes if occurring in other organs might increase the mortality rate above that to be expected from the degree of myocardial necrosis present. The present study of course permits no conclusions about the influence of extracardiac factors on the mortality rate.

It is not likely that the correlations reported here were significantly affected by, nor the result of, the SGOT elevation that may (in the absence of recent myocardial infarction) accompany cardiac failure (West et al., 196r ; Crowley, 1968), paroxysms of tachyarrhythmia (Agress, 1959; Runde and Dale, 1966; West et al., 1966), or direct current countershock (Reinikainen et al., 1965; Mandecki, Giec, and Kargul, 1970). The SGOT rises in about only $I$ in 4 of these cases (West et al., 196I; Runde and Dale, 1966; Crowley, 1968; Mandecki et al., 1970). In the tachycardias, the rise is restricted to cases with a ventricular rate above 160 beats a minute (West et al., 1966). With cardioversion, it occurs only if two or more shocks are given (Mandecki et al., 1970). When an increase does occur, the height to which the serum level rises is seldom more than moderate (West et al., 196I ; Runde and Dale, 1966; Mandecki et al., 1970). In the present series, cardiac failure was present in 75.8 per cent of cases. The incidence of the ectopic tachyarrhythmias ranged from $1 \mathrm{I} \cdot 7$ per cent for ventricular tachycardia to 13.9 per cent for atrial fibrillation. In many cases, the maximum ventricular rate did not exceed I60 beats a minute. Less than Io per cent of cases underwent cardioversion or defibrillation, and in some of these only one shock was given. An increase of SGOT from these causes is therefore unlikely to have had much 
effect on the results. Such an increase, moreover, would neither influence nor explain complications other than cardiac failure, rapid tachyarrhythmias, and cardiac arrest. As stated previously (Chapman, I97Ib), cases with a concurrent extracardiac cause for enzyme elevation were excluded from the analysis.

The findings presented here are supported by the fact that similar correlations were found for the incidence of the same complications on the serum levels of both lactic dehydrogenase and creatine phosphokinase (Chapman, unpublished observations). Though the lactic dehydrogenase may rise in cardiac failure (West et al., I96I ; Crowley, I968) or paroxysmal tachyarrhythmia (Runde and Dale, 1966), the creatine phosphokinase does not rise (West et al., 1966; Crowley, I968; Savignano, Hanok, and Kuo, 1969). After cardioversion the creatine phosphokinase rises appreciably in about one case in two, but the lactic dehydrogenase rises little if at all (Mandecki et al., 1970). Thus, the three enzymes have different patterns of response to cardiac failure, tachyarrhythmia, and cardioversion, but all have a similar, highly significant linear relation to the incidence of the cardiac complications studied.

Little published work correlating the incidence of these complications with the extent of infarction could be found. Keele, Goulden, and Newman (1958) showed that as the SGOT level rose, so did the incidence of heart failure and hypotension. In a series of reports from the Royal Melbourne Hospital, increasingly severe infarcts were shown to be associated with an increasing incidence of supraventricular and ventricular arrhythmias (Stock, Goble, and Sloman, 1967), heart block (Goble, Sloman, and Robinson, I966), and bundle-branch block (Hunt and Sloman, 1969). However, the severity of infarction was judged clinically, according to the degree of myocardial decompensation present on admission (Robinson, Sloman, and McRae, 1964). The present report shows that the incidence of myocardial insufficiency is itself a reflection of the more basic enzyme levels. In another paper from the Melbourne group (Stannard and Sloman, 1967), atrial fibrillation was reported to be associated with high SGOT and lactic dehydrogenase levels, but its incidence at various levels was not given. Mogensen (1970) showed that increasing SGOT levels were usually associated with an increasing incidence of ventricular arrhythmias, heart block, bundle-branch block, and myocardial decompensation. However, the SGOT values were analysed into only three broad class intervals. Furthermore, the linear nature of the relation was not demonstrated.

Grateful acknowledgement is made of the contributions to the project of which this is a part by Dr. J. M. Duggan, Dr. J. T. Holland, Dr. J. N. Walker, and many other members of the Royal Newcastle Hospital staff; by Mr. H. M. Frith and his assistants at the Newcastle Permanent Building Society Limited; and by Mr. C. H. Gray, Mrs. J. Bubb, and other members of the Division of Computing Research, the Scientific and Industrial Research Organization, Sydney. The study could be undertaken only because of generous donations of computer facilities and time by the Newcastle Permanent Building Society Limited and the CSIRO Division of Computing Research, and because of grants made towards the clerical and computer expenses by the Computer Investigation Group of the Hospitals Commission of New South Wales. I am indebted to Miss S. Robinson of the West Middlesex Hospital for drawing the graphs.

\section{References}

Agress, C. M. (1959). Evaluation of the transaminase test. American fournal of Cardiology, 3, 74.

Chapman, B. L. (1970). Hospital mortality of myocardial infarction, before and after coronary care. Medical fournal of Australia, 1, 833.

Chapman, B. L. (I971a). Prognostic factors in acute myocardial infarction treated in a coronary care unit. Australian and New Zealand fournal of Medicine, I, 53.

Chapman, B. L. (197Ib). Correlation of mortality rate and serum enzymes in myocardial infarction. Test of efficiency of coronary care. British Heart fournal, $33,643$.

Crowley, L. V. (1968). Creatine phosphokinase activity in myocardial infarction, heart failure, and following various diagnostic and therapeutic procedures. Clinical Chemistry, 14, 1185.

Goble, A. J., Sloman, G., and Robinson, J. S. (1966). Mortality reduction in a coronary care unit. British Medical fournal, 1, 1005 .

Hunt, D., and Sloman, G. (1969). Bundle-branch block in acute myocardial infarction. British Medical fournal, $\mathbf{1}, 85$.

Keele, K. D., Goulden, F., and Newman, M. J. D. (1958). Prognostic and diagnostic value of serum glutamic oxaloacetic transaminase in suspected cardiac infarction. Lancet, 2, 1187.

Kibe, O., and Nilsson, N. J. (1967). Observations on the diagnostic and prognostic value of some enzyme tests in myocardial infarction. Acta Medica Scandinavica, 182, 597.

Killen, D. A., and Tinsley, E. A. (1966). Serum enzymes in experimental myocardial infarcts. Archives of Surgery, 92, 418.

Mandecki, T., Giec, L., and Kargul, W. (I970). Serum enzyme activities after cardioversion. British Heart fournal, 32, 600 .

Mogensen, L. (1970). Ventricular tachyarrhythmias and lignocaine prophylaxis in acute myocardial infarction. A clinical and therapeutic study. Acta Medica Scandinavica, Suppl. 5 I 3.

Page, D. L., Caulfield, J. B., Kastor, J. A., DeSanctis, R. W., and Sanders, C. A. (1971). Myocardial changes associated with cardiogenic shock. New England Fournal of Medicine, 285, 133. 
Reinikainen, M., Koskinen, P., Pöntinen, P., and Siitonen, L. (1965). Experiences in the use of direct current countershock in the treatment of cardiac arrhythmias. Acta Medica Scandinavica, Suppl. 437.

Robinson, J. S., Sloman, G., and McRae, C. (1964). Continuous electrocardiographic monitoring in the early stages after acute myocardial infarction. Medical fournal of Australia, 1, 427.

Runde, I., and Dale, J. (1966). Serum enzymes in acute tachycardia. Acta Medica Scandinavica, 179, 535.

Savignano, T., Hanok, A., and Kuo, J. (1969). Creatine phosphokinase activity. A study of normal and abnormal levels. American fournal of Clinical Path$\operatorname{olog} y, 51,76$.

Stannard, M., and Sloman, J. G. (1967). Atrial fibrillation in acute myocardial infarction. Medical fournal of Australia, 1, 1250.

Stock, E., Goble, A., and Sloman, G. (1967). Assessment of arrhythmias in myocardial infarction. British Medical fournal, 2, 719.
West, M., Eshchar, J., and Zimmerman, H. J. (1966). Serum enzymology in the diagnosis of myocardial infarction and related cardiovascular conditions. Medical Clinics of North America, 50, 171 .

West, M., Gelb, D., Pilz, C. G., and Zimmerman, H. J. (196I). Serum enzymes in disease. VII. Significance of abnormal serum enzyme levels in cardiac failure. American fournal of the Medical Sciences, 24I, 350.

Whitby, G. (1968). The enzyme response of the myocardium to ischaemia and infarction. In Acute Myocardial Infarction: Proceedings of a Symposium, University of Edinburgh, 1967, p. 266. Ed. by D. G Julian and M. F. Oliver. Livingstone, Edinburgh and London.

Requests for reprints to Dr. B. L. Chapman, West Middlesex Hospital, Isleworth, Middlesex. 